\title{
Energy Recovery from Solid Waste for Nazareth/Adama City, Ethiopia
}

\author{
Melaku Tafese Awulachew \\ Department of Food Science and Nutrition Research Process, Ethiopian Institute of Agricultural Research, Kulumsa Agricultural Research \\ Center, Assela, Ethiopia
}

Email address:

Melakutafese12@gmail.com

\section{To cite this article:}

Melaku Tafese Awulachew. Energy Recovery from Solid Waste for Nazareth/Adama City, Ethiopia. International Journal of Energy and Environmental Science. Vol. 4, No. 3, 2019, pp. 35-46. doi: 10.11648/j.ijees.20190403.11

Received: May 5, 2019; Accepted: April 15, 2019; Published: July 23, 2019

\begin{abstract}
Major problems facing modern society include the provision of energy with the minimum generation of pollution, and the environmentally friendly disposal of waste. This work was part of a major study that examined the policy and technology implications of alternatives for managing the municipal solid wastes (MSW) of Adama (Nazareth) City (Town). Consequently, to accomplish the objectives both primary and secondary data sources applied for the study. The primary data were collected via questionnaires, interview, and field observations. Whereas the secondary data were extracted from different published and unpublished materials. At this time, of the 71700 metric tons of MSW collected by the town annually are land filled. Despite the heterogeneity of organic materials in MSW, the composite molecular structure can be approximated by the organic compound $\mathrm{C} 6 \mathrm{H} 10 \mathrm{O} 4$. A formula was derived that allows the prediction of the heating value of MSW as a function of moisture content and compares well with experimentally derived values. The performance of a leading Waste-to-Energy plant that utilizes suspension firing of shredded MSW, processes one 71700 metric tons of MSW per year, and generates a net of 3.1 MW/yr electricity was examined. The results of this study showed that WTE processing of the MSW reduces fossil fuel consumption and is environmentally superior to land filling.
\end{abstract}

Keywords: Municipal Solid Waste, Energy Recovery, Waste-to-Energy Balance, Equipment Sizing, Feasibility Cost Analysis

\section{Introduction}

One of the greatest challenges facing developing countries is the unhealthy disposal of solid waste which resulted from human activities of development and survival [1]. Most human activities certainly result in the generation of waste which tends to increase with rapid urbanization, improved living standards and changing consumption patterns [2-3]. Solid Waste Management is a vital, ongoing and large public service system, which needs to be efficiently provided to the community to maintain aesthetic and public health standards [4]. The poor state of waste management in the country is caused by inadequate facilities, poor funding, and poor implementation of policies as well as wrong lifestyle. Reviews show that in urban areas, especially in the rapidly urbanizing cities problems and issues of municipal solid waste management (MSWM) are of immediate importance. Most governments have acknowledged the importance of
MSWM; however, a rapid population growth overwhelms the capacity of most municipal authorities to provide even the most basic services [14].

The economic development and prosperity are accompanied by the generation of large amounts of wastes that must be re-used in some way or disposed in landfills. Waste generation can be reduced to some extent by improved design of products and packaging materials and by increasing intensity of service per unit mass of material used. However, even after such measures are taken, there will remain a large amount of solid wastes to be disposed of. Solid wastes can be classified into municipal (residential and commercial), industrial, construction and demolition wastes. The municipal solid wastes (MSW) are the most non homogeneous since they consist of the residues of nearly all materials used by humanity: Food and other organic wastes, papers, plastics, fabrics, leather, metals, glass and miscellaneous other materials. Processing or disposal of MSW requires separating 
the MSW into a number of streams and subjecting each stream to the most appropriate method of resource recovery.

The aim of this study is to address the health and environmental problem by produce sufficient energy from solid waste that helps the solid waste management system of Nazareth town. Significance of the study is to Increase government revenue, and fulfill social need, Create employments and job opportunity for people, reduces cost spent for electricity and reduce dependent on fossil fuel.

\subsection{Solid Waste Management in Adama/Nazareth City}

Adama city is located at about $100 \mathrm{~km}$ southeast of Addis Ababa on the high way to Djibouti.

The separation of MSW components can take place at the source, i.e. households or businesses, or at Materials Recovery Facilities (MRFs) using manual and electromechanical methods. There are four principal methods for resource recovery or disposal of MSW:

a Recovery of materials: Recovered paper, plastic, metal, and glass can be re-used.

b Recovery of energy: Energy is stored in chemical form in all MSW materials that contain organic compounds, i.e. everything except metals, glasses, and other inorganic materials. The combustion of these compounds can generate electricity and steam.

c Bioconversion: The natural organic components of MSW (food and plant wastes, paper, etc.) can be composted aerobically (i.e., in the presence of oxygen) to carbon dioxide, water, and a compost product that can be used as soil conditioner. Anaerobic digestion or fermentation produces methane or alcohol and a compost product.

d Land filling: MSW materials that cannot be subjected to any of the above three methods, plus any residuals from these processes (e.g., ash from combustion) must be disposed in properly designed landfills.

\subsection{Collection of Waste}

\subsubsection{Primary Solid Waste Collection}

Primary collection operation enables to transfer solid waste from the sources of generation to the secondary collection facilities/containers. The identified operational modes of primary collection in Adama city are:

a. Door to door collection:

Regarding door-to-door solid waste collection, households have two options.

The first option is that households take their solid wastes and dispose it in to a container nearest to their home.

The second option is having contract agreement with micro and small enterprise associations to take their wastes to the container. These micros have different material capacity and manpower. Most of them have hand pushed carts and some of them have horse drawn carts. They are serving for more than 2000 households and organizations. They have more than 50 youth workers.

One can observe that most households prefer the first option. This is because it has no collection cost that most households especially low income families prefer. Some middle and most high-income households prefer the second option. According to some surveys, estimation a household should get a container within 200 meters of his vicinity, and one container provides services to a maximum of 2000 people. Based on this estimation, only $48.1 \%$ of the households are found within the service area of the container.

b. Street Sweeping

Though inadequate the municipality provides street sweeping services twice in a day for a total of $58 \mathrm{Km}$. The mode of the service is provided by:

Municipality sanitation workers and three MSE's using tools like straw brooms, wheel barrow and shovel.

Street side posted public dust bins for street users and pedestrians are expected to drop their solid waste piece in the public garbage bins when they are out of their homes and business offices. Wheel barrows are used for primary collection of wastes from street to dump into the municipality assigned two trucks. The annual solid waste collection by the street sweepers is $2340 \mathrm{~m}^{3}$. This comprises $63 \%$ is collected out of the $3750 \mathrm{~m}$ cube waste generated from the streets. The low performance is due to the dust bins are inadequate and at the same time the public didn't aware and bring attitudinal change to drop solid wastes, especially paper and plastic materials (festal) on the dust bins.

\subsubsection{Secondary Collection and Transportation}

In Nazareth town the secondary waste collection activity is carried out solely by municipality through:

a. Two Skip Loaders

Communal storage of primarily collection allows the safe retention of the solid waste for a sufficient period of time between primary collection from the different sources and secondary collection and disposal of the solid waste.

In the present context of solid waste management in the city, the municipality is the only institution that provides communal storages and performs secondary collection to the disposal sites. The municipality performs the storage task with a total of 31 communal containers that can be easily mounted on skip loaders to be transported the land fill sites.

This communal storage SSWM has major problems:-

Most of these containers are cited at 10 meters from the premises of the households where as the Sanitation Regulation of the city oblige residences to clean 10 meter radius of their perspective premises is abused by the municipality. Such type of service is against the sanitation regulations and constitutional rights of the residences to live in a clean environment as the result of bad odor from the communal containers.

Trucks have a carrying capacity of weighed 100 to 120 quintals at a time but the skip loaders equipped with a hydraulic lifting mechanism are designed to lift 30 quintals garbage filled contained at a time. As a consequence the trucks are working at $25-30 \%$ efficiency because of the existing communal container based solid waste collection, transportation and disposal system in use. 
These skip loaders transport the 30 communal containers cited in different part of the city. Each skip loader is expected to cover 8 trips in a day but due to technical and others problems they transport and dispose $25520 \mathrm{~m}^{3}$ at an efficiency of $62 \%$

b. Two old Trucks

These trucks also providing a primary and secondary waste collection with a capacity of $7 \mathrm{~m}^{3}$ and $8 \mathrm{~m}^{3}$; mainly giving a service to the down city parts with high waste regeneration and streets. These trucks collect and dispose $9401 \mathrm{~m}^{3}$ under efficiency $51 \%$ [5].

\subsection{Disposal of Waste}

The former final disposal site is found on the southwest direction, $9 \mathrm{~km}$ away from the town (on the road to Addis Ababa around the wind power). The town uses the lowest type of disposal system that is open dumping. All types of solid wastes generated in the city are dumped indiscriminately at the final disposal site. The total area coverage is $14,000 \mathrm{~m}^{2}$.

\subsection{Basic Techniques of Energy Recovery}

Energy can be recovered from the organic fraction of waste (biodegradable as well as non-biodegradable) basically through two methods as follows:

a. Thermo-chemical conversion: This process entails thermal de-composition of organic matter to produce either heat energy or fuel oil or gas and

b. Bio-chemical conversion: This process is based on enzymatic decomposition of organic matter by microbial action to produce methane gas or alcohol.

The Thermo-chemical conversion processes are useful for wastes containing high percentage of organic nonbiodegradable matter and low moisture content.

\subsubsection{Parameters Affecting Energy Recovery}

The main parameters which determine the potential of Recovery of Energy from Wastes

(Including MSW) are:

a. Quantity of waste

b. Physical and chemical characteristics of the waste

The actual production of energy will depend upon specific treatment process employed. The important physical parameters requiring consideration include: size of constituents, density and moisture content.

Smaller size of the constituents aids in faster decomposition of the waste. Wastes of the high density reflect a high proportion of biodegradable organic matter and moisture. Low density wastes on the other hand indicate a high proportion of paper plastics and other combustibles. High moisture content causes biodegradable waste fractions to decompose more rapidly than in dry conditions.

The important chemical parameters to be considered for determining the energy Recovery potential and the suitability of waste treatment through bio-chemical or thermo chemical conversion technologies include: - Volatile Solids, Fixed Carbon content, Inert, Calorific Value, $\mathrm{C} / \mathrm{N}$ ratio (Carbon/Nitrogen ratio) and Toxicity.

However, the components of the wastes vary increasingly with the life style and economic standards of the population. It is therefore necessary to know the exact composition of wastes under study.

The basic component materials in the citywide waste stream can be classified as: Organic or put rescible materials, Paper and cardboard, Plastics and rubber, Glass, Metals and cans, Textile, Inert or residues and Miscellaneous or other waste.

Below is the composition of solid wastes in various studies

Table 1. Composition of municipal waste arising in the European country [6].

\begin{tabular}{|c|c|c|c|c|c|c|c|c|c|c|}
\hline Component & U.K & F.R.G & France & Denmark & Italy & Ire-land & Belgium & Lusxburg & Netherland & Average EEC \\
\hline Putrescibe & 21 & 16 & 20 & 15 & 39 & 28 & 43 & 56 & 48 & 25.4 \\
\hline Paper \&board & 30 & 27.5 & 35 & 35 & 24 & 33 & 30 & 25 & 23 & 28.7 \\
\hline Textile & 3 & 3 & 4 & 2 & 3.5 & 3 & 2 & 1.5 & 1.8 & 3.1 \\
\hline Plastic & 3 & 4 & 5 & 4 & 6.5 & 4 & 4 & 4.6 & 6 & 4.6 \\
\hline Glass & 9 & 9 & 8 & 8 & 5.5 & 8 & 10 & 5.2 & 1.3 & 8.3 \\
\hline Metal & 9 & 6.5 & 5 & 4 & 3.5 & 4 & 5 & 3.6 & 2.9 & 6.0 \\
\hline \multirow{2}{*}{ Ashes, dust \&other total } & 25 & 34 & 23 & 32 & 18 & 20 & 6 & 4.1 & 5.3 & 23.9 \\
\hline & 100 & 100 & 100 & 100 & 100 & 100 & 100 & 100 & 100 & 100 \\
\hline Mean calorific value $\mathrm{kj} / \mathrm{kg}$ & 9400 & 7500 & 8400 & 8400 & 6750 & 9400 & 7300 & 7500 & 7500 & 7500 \\
\hline $\mathrm{Kcal} / \mathrm{kg}$ & 2250 & 1800 & 2000 & 2000 & 1300 & 2250 & 1750 & 1800 & 1800 & 1800 \\
\hline
\end{tabular}

Table 2. Some comparisons in waste characteristics [7].

\begin{tabular}{llll}
\hline Component & United kingdom & Asian city & Middle East city (OPEC) \\
\hline Vegetables & 28 & 75 & 50 \\
Paper & 37 & 2 & 16 \\
Textile & 3 & 3 & 3 \\
Plastic & 9 & 0.2 & 2 \\
Metal & 9 & 0.1 & 5 \\
Other Total & $12 / 100$ & $18.7 / 100$ & $23 / 100$ \\
Density $\left(\mathrm{kg}^{3} \mathrm{~m}^{3}\right)$ & 132 & 570 & 211 \\
Weight person & day $^{-1}(\mathrm{~kg})$ & 0.415 & 1.06 \\
Weight household & day & \\
\end{tabular}




\subsubsection{Assessment of Energy Recovery Potential from Solid Waste}

A detailed assessment of the potential of recovery of energy from MSW through different treatment methods can be made from knowledge of its calorific value and organic fraction. In order to evaluate the feasibility of energy recovery from MSWs, it is of great importance to determine the energy content or calorific value $(\mathrm{CV})$ of the solid waste, which is defined as the number of heat units evolved when unit mass of material is completely burned and is measured in joules per gram $(\mathrm{J} / \mathrm{g})$ or British thermal units per pound $(\mathrm{Btu} / \mathrm{lb})$. The energy content of any material, such as solid waste, is a function of many parameters, namely, physical composition of the waste, moisture content and ash content. There are several experimental and empirical approaches available for determining the CV of materials such as MSW. Calorimetric measurement is the common method for determining the energy content of MSW. One method of determining the $\mathrm{CV}$ of a given material is by means of an open calorimeter in which pressure is maintained at 1atmosphere. Under constant pressure conditions, the heat released is equal to the enthalpy change for the reaction. Another type of calorimeter is the bomb calorimeter in which Combustion is conducted under conditions of constant volume. Regarding the empirical approaches, there are three types of models that are used to predict $\mathrm{CV}$ values based on the following analyses.

1. Physical composition

2. Ultimate analysis

3. Proximate analysis

Determination of the energy content of the MSW is not an easy task. This is because of the equipment limitation and the complex nature of the wastes. Also, MSW composition varies amongst communities and even within one community from year to year, but the differences is not substantial. Below is the energy content of various types of waste components. The Typical heating values of principal constituents of municipal wastes is given below;

Table 3. Heating value of each component of solid waste [8].

\begin{tabular}{ll}
\hline Component & calorific value $(\mathbf{M J} / \mathbf{K G})$ \\
\hline Paper and paper products & $12.23-18.56$ \\
Plastic-coated paper & 17.09 \\
Food and food waste & $4.12-38.33$ \\
Wood, seasoned & $14.97-17.00$ \\
Organic garden refuse & $4.79-18.59$ \\
Tyres & 32.12 \\
Leather goods & $16.86-18.53$ \\
Rubber & 26.07 \\
Plastics & \\
Polyethylene & 45.81 \\
Polystyrene & 38.22 \\
PVC & 22.71 \\
Mixed plastics & 32.82 \\
Textiles & \\
Rags & 16.06 \\
Upholstery & 16.20 \\
\hline
\end{tabular}

Incineration of solid waste for energy recovery
Incineration is defined as "reducing the volume of solid wastes by use of an enclosed device, using controlled-flame combustion". It is a thermal waste treatment process where raw or unprocessed waste can be used as feedstock. The incineration process takes place in the presence of sufficient quantity of air to oxidize the feedstock (fuel). Waste is combusted at high temperature and in this stage waste converted to carbon dioxide, water and non-combustible materials with solid residue state called incinerator bottom ash (IBA) that always contains a small amount of residual carbon. It is the process of direct burning of wastes in the presence of excess air (oxygen) at temperatures of about $800^{\circ}$ and above, liberating heat energy, inert gases and ash. Net energy yield depends upon the density and composition of the waste; relative percentage of moisture and inert materials, which add to the heat loss; ignition temperature; size and shape of the constituents; design of the combustion system (fixed bed/ fluidized bed), etc. In practice, about 65 to $80 \%$ of the energy content of the organic matter can be recovered as heat energy, which can be utilized either for direct thermal applications, or for producing power via steam turbine.

The combustion temperatures of conventional incinerators fuelled only by wastes are about $870^{\circ} \mathrm{C}$ in the furnace. These temperatures are needed to avoid odor from incomplete combustion but are insufficient to burn or even melt glass. To avoid the deficiencies of conventional incinerators, some modern incinerators utilize higher temperatures of up to $1650^{\circ} \mathrm{C}$ using supplementary fuel. These reduce waste volume by $97 \%$ and convert metal and glass to ash. Wastes burned solely for volume reduction may not need any auxiliary fuel except for start-up. When the objective is steam production, supplementary fuel may have to be used with the pulverized refuse, because of the variable energy content of the waste or in the event that the quantity of waste available is insufficient. Incineration may also be implemented without energy and materials recovery. In some countries, incinerators built just a few decades ago often did not include a materials separation to remove hazardous, bulky or recyclable materials before combustion. These facilities tended to risk the health of the plant workers and the local environment due to inadequate levels of gas cleaning and combustion process control. Most of these facilities did not generate electricity [9]).

\subsubsection{Principles of Incineration}

Incineration facilities may use either mass burning systems or prepared fuel systems.

a. Mass burning systems- involve feeding mixed municipal solid waste into a furnace or boiler without mechanically separating or preparing the waste in any way. These facilities can be either large field-erected furnace-boiler systems or smaller modular furnace-boiler systems.

b. Prepared fuel systems- mixed municipal solid waste is mechanically separated and processed to make RDF either as a supplemental fuel for an existing furnace- 
boiler or to be used alone in a dedicated furnace-boiler.

From the experiences of some Developed countries, Energy recovery is rarely associated with small incinerators; incinerators burning less than 250 tons per day do not produce cost effective steam. This steam can then be used to generate electricity, power industrial processes, or provide heat. Incinerators may be classified in a variety of fashions.

This classification can have one of the following forms:

By type and form of the waste input.

1. By the throughput capacity (with or without heat recovery).

2. By the rate of heat production (for systems with energy recovery).

3. By the state in which the residue emerges from the combustion chamber and

4. By the shape and number of furnaces (e.g., rectangular, multiple).

The key system elements involved in the incineration of urban solid wastes are: Tipping area, Storage pit, Equipment for charging the incinerator, Combustion chamber, Bottom ash removal system, and Gas cleaning equipment (i.e., air pollution control system). If energy is to be recovered, a Boiler is included.

\subsubsection{Combustion Air}

Combustion air may be classified either as "under-fire" or as "over-fire" air. Under-fire air is that which is forced into the furnace through and around the grates. Over-fire air is forced into the furnace through the sides or the ceiling. Over-fire air typically is introduced through jets located at specific points in the furnace. It is used to regulate and complete the combustion of combustible gases evolved by the thermal reactions that are occurring in the lower part of the furnace. The flow of air and combustion gases through the furnace can be controlled by means of forced draft and induced draft fans. The forced draft fan, as its name implies, forces air into the furnace, while the induced draft fan draws the air.

\section{Material and Method}

\subsection{Method of Data Collection}

\subsubsection{Primary Data}

During conducting the study in Adama city the following primary information were collected using:-

1. A well structured questionnaire.

2. Interview the organization (private, association and municipality) that are engaged in municipal solid waste management.

3. visual observation

\subsubsection{Secondary Data}

Various laboratory result, literature books, from Adama city administration recorded data and internet have been used to carry out the study.

\subsection{Experimentation}

\subsubsection{Lab Analysis}

I moisture content
$673 \mathrm{~g}$ of wet sample of Solid waste was oven dried at $60^{\circ} \mathrm{C}$ for $6 \mathrm{hr}$ and $626 \mathrm{~g}$ of dry weight was determined. The percent moisture content can be calculated as a percentage loss in weight before and after drying as follows:

$$
\begin{aligned}
\% \text { Moisture content } & =\frac{\text { Wet Weight-Dry Weight }}{\text { Wet Weight }} \times 100 \% \\
& =\frac{673 \mathrm{~g}-626 \mathrm{~g}}{673 \mathrm{~g}} \mathrm{X} 100 \%=7 \%
\end{aligned}
$$

II Composition of solid waste by type

Dry sample gotten (626g) is separated manually and then calculate the composition of each type by mass. The moisture content of the sample is $7 \%$.

Table 4. Laboratory result of solid waste composition of our sample.

\begin{tabular}{lll}
\hline Type & Mass in $(\mathbf{g})$ & \%by mass \\
\hline Paper & 70.5 & 12.26 \\
Plastic & 30.33 & 4.84 \\
Food & 95.15 & 15.2 \\
Wood & 46.52 & 7.43 \\
Textile & 62 & 9.9 \\
Combustible leaves and grass & 83 & 13.25 \\
Fine & 178.5 & 28.5 \\
Metal & 22.536 & 3.6 \\
Stone and glass & 37.56 & 6 \\
\hline
\end{tabular}

This table shows the laboratory result of solid waste composition of Nazareth city. this laboratory activity done for three times by taking the samples of solid waste from different part of city and then determined the composition of these all sample and then this value in table is average value of those sample.

When we compare this composition with literature value it almost exists in the interval of literature value composition of the solid waste.

III Determination of total mass of wastes

The analysis is done for 2006 since it represents the recent data on wastes. A total of $71700 \mathrm{~m}^{3}$ waste is collected in wet basis and the total mass the component is determined by density values of the components and the total volume of waste $(\mathrm{m}=\rho \mathrm{v})$.

Hence calculate the dry mass of total waste;

Dry mass $=93 \% \times$ total mass in wet basis

$$
=0.93 \times 71700 \mathrm{~m}^{3}=66681 \mathrm{~m}^{3}
$$

Combustible Components

a. Mass of paper

$$
\rho=150.66 \mathrm{~kg} / \mathrm{m}^{3} \text { (average value) }
$$

Mass of paper $=\%$ paper $\mathrm{x}$ density $\mathrm{x}$ total volume

$$
\begin{aligned}
& =0.1126 X 150.66 \mathrm{~kg} / \mathrm{m}^{3} \times 66681 \mathrm{~m}^{3} / \text { year } \\
& =1131197.555 \mathrm{Kg} / \text { year }
\end{aligned}
$$

b. Mass of plastics

$$
\rho=72 \mathrm{~kg} / \mathrm{m}^{3} \text { (average value) }
$$


Mass of plastics $=\%$ plastics $\mathrm{x}$ density $\mathrm{x}$ total volume

$$
\begin{aligned}
& =0.0484 \times 72 \times 66681 \\
& =232369.95 \mathrm{~kg} / \text { year }
\end{aligned}
$$

c. Mass of Food waste

$$
\rho=628.66 \mathrm{~kg} / \mathrm{m}^{3} \text { (average value) }
$$

Mass of food waste $=\%$ food waste $\mathrm{x}$ density $\mathrm{x}$ total volume

$$
\begin{aligned}
& =0.152 \times 628.66 \times 66681 \\
& =6371790.974 \mathrm{~kg} / \text { year }
\end{aligned}
$$

d. Mass of wood waste

$$
\rho=156 \mathrm{~kg} / \mathrm{m}^{3} \text { (Average value) }
$$

Mass of wood waste $=\%$ wood waste $\mathrm{x}$ density $\mathrm{x}$ total volume

$$
\begin{aligned}
& =0.0743 \times 156 \times 66681 \\
& =772886.13 \mathrm{~kg} / \text { year }
\end{aligned}
$$

e. Mass of Textiles

$$
\rho=140.66 \mathrm{~kg} / \mathrm{m}^{3} \text { (average value) }
$$

Mass of textiles $=\%$ textiles $\mathrm{x}$ density $\mathrm{x}$ total volume

$$
\begin{aligned}
& =0.099 \times 140.66 \times 66681 \\
& =928555.59 \mathrm{~kg} / \text { year }
\end{aligned}
$$

f. Mass of combustible leaves, Grass

$$
\rho=254.33 \mathrm{~kg} / \mathrm{m}^{3} \text { (average value) }
$$

Mass of combustible leaves, Grass $=\%$ leaves $\mathrm{x}$ density $\mathrm{x}$ total volume

$$
\begin{gathered}
=0.1325 \times 254.33 \times 66681 \\
=2247064.68 \mathrm{Kg} / \text { year }
\end{gathered}
$$

g. Mass of Fines

$$
\rho=300 \mathrm{Kg} / \mathrm{m}^{3} \text { (average value) }
$$

Mass of fines $=\%$ fines $\mathrm{x}$ density $\mathrm{x}$ total volume

$$
=0.285 \times 300 \times 66681=5701225.5 \mathrm{Kg} / \text { year }
$$

Total mass of combustibles $=11013299.4 \mathrm{Kg} /$ year so the combustible components generated annually are summed up to give 11013.299tons/year.

\section{Incombustible Components}

h. Mass of metal

Mass of metal $=\%$ metal $\mathrm{x}$ density $\mathrm{x}$ total volume

$$
\begin{aligned}
& =0.036 \times 120 \times 66681 \\
& =288061.92 \mathrm{~kg} / \text { year }
\end{aligned}
$$

i. Mass of stone, glass and non combustible component
Mass of $=\%$ stone, glass and $\mathrm{NC} \times \mathrm{x}$ density $\mathrm{x}$ total volume

$$
\begin{aligned}
& =0.06 \times 411 \times 66681 \\
& =1644353.46 \mathrm{~kg} / \text { year }
\end{aligned}
$$

The incombustible components are summed up to give $1932415.38 \mathrm{Kg} /$ year (1932.415ton/year)

The total mass of combustible and incombustible components generated annually $12945714.78 \mathrm{~kg} /$ year (12945.714ton/year).

Determination of ash content

Ash content of solid waste is determined by burning the solid waste that contain all components in proportion and then balance the ash after the ignition is happened. According to our project we are taken $100 \mathrm{~g}$ of our sample for ignition in the furnace and we have gotten $20 \mathrm{~g}$ of ash. Those, solid waste in Nazareth town have been determine about $20 \%$ of ash content.

The ash meets the EPA non-toxic criteria (TCLP test, Wiles 1997) and can be used as landfill cover and in other beneficial uses.

IVHeating value determination

One method of determining the $\mathrm{CV}$ of a given material is by means of bomb calorimeter in which pressure compressed in compressor is maintained at 3 atmospheres. This type of calorimeter is in which combustion is conducted under conditions of constant volume. In order to determine the CV of MSW, samples of MSW are selected combustible part from solid waste sample (food, paper, plastic, grass, wood, textile, fine). The CV can be measured for each of the components individually by burning a weighed sample in an oxygen bomb calorimeter and measure the reference and final temperature.

We were prepared the sample as a powder form and $1 \mathrm{~g}$ of sample was pressed by sample presser, then Placed the sample in the bomb and 3atm oxygen gas was compressed on the bomb. Then we put the bomb on the calorimetric and add distilled water to the calorimeter and connect the bomb calorimeter with digital thermometer to read the temperature, finally we were start ignition and read temperature.

Table 5. Heating value of MSW (MJ/kg).

\begin{tabular}{ll}
\hline Type & Heating value $(\mathbf{M J} / \mathbf{k g})$ \\
\hline Paper & 15.3995 \\
Plastic & 32.83 \\
Food & 21.225 \\
Wood & 15.985 \\
Textile & 16.06 \\
Combustible leaves and grass & 11.69 \\
Fine & 8.534 \\
\hline
\end{tabular}

The annual generation rate and the corresponding heating values of each component of MSW are taken in to account to compute the available energy. The heating value of each component is calculated from the basic thermodynamic equation;

$\mathrm{Q}=\mathrm{m} \times \mathrm{q}$

Where $\mathrm{Q}=$ the available heat in the component stream 
$\mathrm{m}=$ the mass of the component (annually generated)

$\mathrm{q}=$ the specific heat of the component

For Paper

For better computation the average calorific values are taken

$\mathrm{Q}=\mathrm{m} \times \mathrm{q}$

$\mathrm{m}=$ the annual generation of paper $=1131197.55 \mathrm{~kg} / \mathrm{year}$

$\mathrm{q}=15.395 \mathrm{MJ} / \mathrm{kg}$

$\mathrm{Q}=1131197.55 \mathrm{~kg} /$ year $\quad \mathrm{x} \quad 15.395 \mathrm{MJ} / \mathrm{kg}$

$17414786.28 \mathrm{MJ} /$ year

For plastics (mixed)

$\mathrm{Q}=\mathrm{m} \times \mathrm{q}=232369.95 \times 32.83=7628705.459 \mathrm{MJ} /$ year

For Food waste

$\mathrm{Q}=\mathrm{m} \times \mathrm{q}=637179.97 \times 21.225=13524144.86 \mathrm{MJ} /$ year

For Wood waste

$\mathrm{Q}=\mathrm{m} \times \mathrm{q}=772886.1 \times 15.985=12354584.31 \mathrm{MJ} /$ year

For Textiles

$\mathrm{Q}=\mathrm{m} \times \mathrm{q}=928555.59 \mathrm{~kg} /$ year $\times 16.06 \mathrm{MJ} / \mathrm{kg}$

$=149126002.78 \mathrm{MJ} /$ year

For combustible leaves and grass

$\mathrm{Q}=\mathrm{m} \quad \mathrm{x} \quad \mathrm{q} \quad=2247064.68 \mathrm{Kg} / \mathrm{year} \quad \mathrm{x} \quad 11.69 \mathrm{MJ} / \mathrm{kg}$

$=2626818.11 \mathrm{MJ} /$ year

For Fines

$\mathrm{Q}=\mathrm{m} \quad \mathrm{x} \quad \mathrm{q} \quad=5701225.5 \mathrm{Kg} /$ year $\quad \mathrm{x} \quad 8.534 \mathrm{MJ} / \mathrm{kg}$

$=48654258.42 \mathrm{MJ} /$ year

Total available energy

The available heat in the combustible components of MSW is summed up to give

$\mathrm{Q}_{\text {combustibles }}=233914513.9 \mathrm{MJ} /$ year

$=233914.5139 \mathrm{GJ} /$ year

$\mathrm{V}$ Heat loss due to moisture

The presence of moisture affects the available heating value. Therefore it is necessary to account for this effect. Based on the laboratory result wastes from Nazareth town contains around $7 \%$. So this value is taken for the analysis.

The heat required to completely vaporize the moisture in the waste stream at $100^{\circ} \mathrm{C}$ is calculated as $\mathrm{Q}_{\mathrm{H} 2 \mathrm{O}}=$ mass of moisture in MSW $\mathrm{x}$ heat capacity of water in MSW $\mathrm{x}$ change in temperature

$\mathrm{Q}_{\mathrm{H} 2 \mathrm{O}}=\mathrm{m} \times \mathrm{c}_{\mathrm{p}} \times \Delta \mathrm{T}$

But $\Delta \mathrm{T}$ the deference between final temperature $\left(100^{\circ} \mathrm{C}\right)$ and initial temperature of water in MSW assumed to be the average annual temperature in Adama $\left(28^{\circ} \mathrm{C}\right)$.

$\Delta \mathrm{T}=(100+273)-(28+273)=72 \mathrm{~K}$.

The mass of moisture is given as

$\mathrm{m}=\%$ moisture $\mathrm{x}$ density $\mathrm{x}$ total volume

$\rho=965 \mathrm{Kg} / \mathrm{m}^{3}$ [density of impure water]

$\mathrm{m}=0.07 \times 965 \mathrm{Kg} / \mathrm{m} 3 \times 71700 \mathrm{~m}^{3}$

$\mathrm{m}=4843335 \mathrm{Kg} /$ year

Thus the heat loss due to the moisture in the feed is $\mathrm{Q}_{\mathrm{H} 2 \mathrm{O}}$

$=4843335 \mathrm{Kg} /$ year $\times 0.0042 \mathrm{MJ} / \mathrm{KgK} \times 72 \mathrm{~K}$

$\mathrm{Q}_{\mathrm{H} 2 \mathrm{O}}=1464624.5 \mathrm{MJ} /$ year

\subsubsection{Method of Energy Recovery Process}

Solid waste generation

Solid waste generate from different sources in Nazareth

(Adama) town such as; households, Street, commercial and institutional firms, industries, hotels and hospitals.

Solid waste collection and storage

solid waste collection is handled in three ways: door-todoor collection for households along accessible streets; block collection for clients (large hotels, enterprises, and institutions) requesting the municipality to provide them with refuse containers and containers system, which expects residents to carry and dump their waste in $10 \mathrm{~m}^{3}$ containers placed supposedly accessible sites. Collect in the waste by using two or more plastic bags for their daily solid waste based on the amount of solid waste that they have been generating daily.

\section{Transportation}

Then transporting the collected solid waste by using pushcarts to temporary storage container and there is large amount of solid waste in temporary storage container then transport to central storage container by using trucks. The vehicles carry only a single container at a time to disposal site. A trip is made to and from collection sites only for single container of maximum capacity of $10 \mathrm{~m}^{3}$ or $2160 \mathrm{~kg}$.

Sorting

After collecting to central storage container sorting the raw material that can be burn and cannot burn in furnace manually.

Size reduction and sieving

Size reduction is an essential step in mechanical processing of mixed wastes and the operation reduces bulky items to particles, the sizes of which are compatible with the processing equipment. Size reduction also brings about a degree of uniformity in terms of the maximum particle size of the diverse components or particle size distribution of the incoming waste stream. The particle size greater than ten millimeter is separate using sieve and recycles again in the crasher.

\section{Incineration}

The most common and list cost form of incineration of MSW is mass burn. This involves a series of furnaces into which the waste is fed and where temperatures are in the region of $850^{\circ} \mathrm{C}$ to $1200^{\circ} \mathrm{C}$ the, optimum temperature being $1100^{\circ} \mathrm{C}$. The waste remains in the furnace for 45 to 70 minutes to ensure complete combustion. There may be auxiliary burners as part of the furnace to ensure that temperatures are maintained. The solid fraction of the combusted waste, the bottom ash is removed via conveyor belt and collected for disposal or further use.

Energy generation

The heat $\left(850-1200^{\circ} \mathrm{C}\right)$ can be used to produce steam in boiler and the compressed steam at high speed move the turbine forms mechanical energy and then the generator changes mechanical energy to electrical energy.

Flue gas treatment

The flue gas constitutes of dust and hazardous substances in gaseous and particulate form that needs to be removed before the flue gas is released into the atmosphere, in order to fulfill the environmental standards. The concentration of the pollutants of the flue gas depends on the waste composition and also on the incineration conditions. The two applied flue 
gas treatment process require bag filters, and wet scrubbers, which are described below.

Wet scrubber

The basic concept for the wet scrubber, is to accelerate the hot flue gas together with injected water so that the water droplets collect the dust particles and precipitate in a settling chamber. The wet scrubbers have a wide area of use, for example when the flue gas contains moisture and acid with separation rate.

Bag filter

Bag filter are widely used in incineration plants. The dustladen gas passes through a filter and is transported through cylindrical bags where the particles are collected, the bag filters has a high cleaning efficiency, with a separation rate of over 99.95 percent. Filtration efficiencies are very high across a wide range of particle sizes.

\subsubsection{Material and Energy Balance}

\section{i Material balance}

From the experimental result we have to sorting the incinerating solid waste material from the total solid waste.

Assumption: The process is steady state, Take basis 1hour, Water inlet on wet scrubber $=1500 \mathrm{~kg} / \mathrm{hr}$, Air inlet in the furnace $=120 \mathrm{~kg} / \mathrm{hr}$, The input that removed (residue) in the wet scrubber is $60 \%, 2 \%$ of the stuck gas in the wet scrubber is water and $5.6 \%$ of input in the bag filter is residue.

a. Material balance on furnace

From general mass balance; Input $=$ output

Solid waste + air $=$ ash + flue gas

$1529.6 \mathrm{~kg} / \mathrm{hr}+120 \mathrm{~kg} / \mathrm{hr}=0.2 \times 1529.6+\mathrm{m}_{1}$

$\mathrm{m}_{1}=1343.68 \mathrm{~kg} / \mathrm{hr}$

b. Material balance on wet scrubber

Input $=$ output

Flue gas + water $=$ stuck gas + waste water

$1343.68 \mathrm{~kg} / \mathrm{hr}+1500 \mathrm{~kg} / \mathrm{hr}=1470 \mathrm{~kg} / \mathrm{hr}+0.6 \mathrm{x}$

$1343.68 \mathrm{~kg} / \mathrm{hr}+\mathrm{m} 2+0.02 \times 1500 \mathrm{~kg} / \mathrm{hr}$

$\mathrm{m}_{2}=537.47 \mathrm{~kg} / \mathrm{hr}$

c. Material balance on bag filter

Input $=$ output

Stuck gas $=$ clean gas + residue $=537.47 \mathrm{~kg} / \mathrm{hr}-0.056 \mathrm{x}$ $537.4 \mathrm{~kg} / \mathrm{hr}=507.4 \mathrm{~kg} / \mathrm{hr}$

Heating value of the combustible component

The component of sample was sorted in each species and balanced the weight to determine the mass fraction of each component and the heating value of the combustible component was determined by bomb calorimeter.

ii Energy balance

Assumption: Energy in = energy out (stead state process), Sensible heat $\mathrm{q}_{\mathrm{S}}$, Latent heat $\mathrm{q}_{\mathrm{L}}$, Boiler, temperature $=210^{\circ} \mathrm{C}$, Inlet temperature of water $=25^{\circ} \mathrm{C}$ and $\mathrm{Cp}$ of water $=4.2 \mathrm{~kJ} / \mathrm{kg}$.

a. Energy balance on furnace

Waste $(1529.6 \mathrm{~kg} / \mathrm{hr}), \quad \mathrm{m}_{1=} 1343.68 \mathrm{~kg} / \mathrm{hr} \quad$ (flue gas), $\mathrm{h}=21248 \mathrm{KJ} / \mathrm{Kg}, \mathrm{h} 1=$ ?

Input $=$ output

The heat content of solid waste $=$ heat loss in to the ash + heat added to the boiler

$1529.6 \mathrm{~kg} / \mathrm{hr} \quad \mathrm{x} \quad 21248 \mathrm{~kJ} / \mathrm{hr}=\mathrm{h} 1 \quad \mathrm{x} \quad 1343.68 \mathrm{~kJ} / \mathrm{kg}$
$+6500188.16 \mathrm{~kJ} / \mathrm{hr}$

$\mathrm{h}_{1}=19350.4 \mathrm{KJ} / \mathrm{kg}$

b. Energy balance on boiler

Assumption:

The energy loss with ash in boiler is neglected.

$\mathrm{m}_{\text {water }} \mathrm{kg} / \mathrm{hr}\left(\mathrm{T}_{\mathrm{i}}=25^{\circ} \mathrm{C}\right), \mathrm{Q}_{\text {in }}(\mathrm{m} \times \mathrm{h}), \mathrm{Q}_{\text {out }}$ (output energy at $\mathrm{T}_{\mathrm{o}}=210^{\circ} \mathrm{C}$ )

From thermodynamics table

$\mathrm{h}_{1} @ 100^{\circ} \mathrm{C}$ saturated liquid $419.1 \mathrm{~kJ} / \mathrm{kg}, \mathrm{h}_{2} @ 100^{\circ} \mathrm{C}$ saturated vapor $2569 \mathrm{~kJ} / \mathrm{kg}, \mathrm{h}_{3} @ 210^{\circ} \mathrm{C}$ super heated saturated vapor $2800 \mathrm{~kJ} / \mathrm{kg}$; qs $=\mathrm{cp} \Delta \mathrm{T}=315 \mathrm{~kJ} / \mathrm{kg}$

Heat gained from furnace $7222.4 \mathrm{kw}$

Energy taken by water in the boiler $=\mathrm{h} 3+\mathrm{h} 2+\mathrm{q}_{\mathrm{s}}=2800$ $+2569+315=5788.1 \mathrm{~kJ} / \mathrm{kg}$

Then the mass of utility required for this duty can be calculated as:

$$
\mathrm{m}_{\text {water }}=\frac{7222.4 \mathrm{kw} \times 3600 \mathrm{se}}{5788.1 \mathrm{~kJ} / \mathrm{kgxhr}}=4497.1 \mathrm{~kg} / \mathrm{hr}
$$

Working energy (output energy) $=m_{\text {water }} \times \mathrm{h}_{3}=$ $4492.1 \mathrm{~kg} / \mathrm{hr} \times 2800 \mathrm{~kJ} / \mathrm{kg}=3493.9 \mathrm{kw}$

c. Energy balance on wet scrubber

Water $1500 \mathrm{~kg} / \mathrm{hr}\left(\mathrm{T}=25^{\circ} \mathrm{C}\right)$, Flue gas $\left(\mathrm{T}=150^{\circ} \mathrm{C}\right)$, stuck gas $\left(\mathrm{T}=70^{\circ} \mathrm{C}\right)$, Out let water $\left(\mathrm{T}=80^{\circ} \mathrm{C}\right)$

The heat loss of the wet scrubber is the product amount of flow and specific heat of water with changing temperature.

$\mathrm{Q}=\mathrm{m}_{\mathrm{w}} \times \mathrm{c}_{\mathrm{p}} \times\left(80^{\circ} \mathrm{C}-25^{\circ} \mathrm{C}\right)=1500 \times 4.2 \times\left(80^{\circ} \mathrm{C}-25^{\circ} \mathrm{C}\right)$ $=346500 \mathrm{~kJ} / \mathrm{hr}$ (loss)

The most common type of turbine used to generate electric city for steam power plant (incineration plant) is jet steam turbine. Mostly the efficiency of jet steam turbine is $80-$ $90 \%$ from this we take $85 \%$ and generator efficiency is $95 \%$. In order to proceed with the next step of converting energy that must be used to calculate the potential energy generation.

The output energy is: $0.85 \times 0.95 \times 25156080 \mathrm{kwh} / \mathrm{year}$

$\mathrm{E}=20313534.6 \mathrm{kwh} /$ year

\subsubsection{Sizing of Main Equipment}

Basis: Solid waste input $1529.6 \mathrm{~kg} / \mathrm{hr}(36710.4 \mathrm{~kg} / \mathrm{day}) ;$ The factory work $24 \mathrm{hr}$ per day and 300 days per year.

a. Design of furnace

1. To design the furnace, the following should be either known or initially assumed

Total required heater duty $[\mathrm{kJ} / \mathrm{hr}]$;

Efficiency $(\eta)$, Fuel value $[\mathrm{kj} / \mathrm{kg}]$, Temperature of inlet air $\left[{ }^{\circ} \mathrm{C}\right]$.

2. 2. Heat librated by fuel (Qf) $=$ Qtot $x \eta=32500.9 \mathrm{MJ} / \mathrm{hr}$ x $0.79=26000.2 \mathrm{MJ} / \mathrm{hr}$

3. Mass of fuel $=\frac{Q t}{q}=32500.9 \mathrm{MJ} / \mathrm{hr} / 21248 \mathrm{Kj} / \mathrm{kg}=$ $1529.6 \mathrm{~kg} / \mathrm{hr}$

4. Total required amount of air $=3 \times$ Mair $=3 \times 29=120$ $\mathrm{kg} / \mathrm{hr}$

5. Inlet heat by air, Qinlet $=$ Mair x CPair $(\Delta \mathrm{T})=29 \mathrm{~kg} \mathrm{x}$ $4.38 \mathrm{~kJ} / \mathrm{kgk} \times 28^{\circ} \mathrm{C}=3556.5 \mathrm{~kJ} / \mathrm{hr}$

6. Heat absorbed by furnace wall, Qwall $=2 \% \mathrm{Qf}=$ $52 \mathrm{MJ} / \mathrm{hr}$

Density air $\left(\rho_{\text {air }}\right)=1.12 \mathrm{~kg} / \mathrm{m}^{3}$ 
7. Volume $=\frac{\text { mass of air }}{\text { Density of air }}=\frac{120}{1.12}=107 \mathrm{~m} 3 / \mathrm{hr}$

The furnace volume required for our purpose is then:

$\mathrm{V}_{\text {total }}=\mathrm{V}_{\text {air }}+\mathrm{V}_{\text {combustible }}$

$\mathrm{V}_{\text {total }}=4.26+107=111.26 \mathrm{~m}^{3}$

The available furnace exists on the market that have relative capacity with our design is $120 \mathrm{~m}^{3}$.

b. Design of boiler

From energy balance the amount of water (utility) entered to the boiler is calculated is $4497.1 \mathrm{~kg} / \mathrm{hr}$.

Thermal conductivity (assume the boiler made of carbon steel and tubular structure) $=0.08 \mathrm{~W} / \mathrm{m}^{2}$

Heat load on the boiler $=9.6 \mathrm{MW}$

$$
\begin{gathered}
\text { Area of the boiler (A) }=\frac{Q \times L}{M \times K \times \Delta T} \\
=9.6 \mathrm{MW} / 4497.1 \mathrm{~kg} / \mathrm{hr} \times 0.04 \mathrm{~W} / \mathrm{m}^{2} \times 185^{\circ} \mathrm{C}=144 \mathrm{~m}^{2}
\end{gathered}
$$

We choose the tube outside diameter $\left(D_{0}\right)=60 \mathrm{~mm}$, inside diameter $\left(\mathrm{D}_{\mathrm{i}}\right)=58 \mathrm{~mm}$ and $\mathrm{L}=8 \mathrm{~m}$

Area of one tube $=\mathrm{L} \times \mathrm{D} \times \pi$

$=8 \mathrm{~m} \times 0.058 \times \pi=1.5 \mathrm{~m}^{2}$

Water mass velocity $=4497.1 \mathrm{~kg} / \mathrm{hr} / 8 \mathrm{~m}^{2}$

$=562.14 \mathrm{kgm}^{2} / \mathrm{hr}$

Number of tube $(\mathrm{n})=\frac{A}{A 1}=144 \mathrm{~m}^{2} / 1.5 \mathrm{~m}^{2}=96$

Total flow area $\left(\mathrm{A}_{\mathrm{f}}\right)={ }_{\pi}^{A 1} \mathrm{D}_{\mathrm{i}}^{2} \times \mathrm{n}$

$=152 \mathrm{~m}^{2}$

As we know the density of water $\left(\rho_{\text {water }}\right)=1000 \mathrm{~kg} / \mathrm{m}^{3}$

Volume of boiler $\left(\mathrm{V}_{\text {water }}\right)=$ mass of water/density of water $=4497.1 \mathrm{~kg} / \mathrm{hr} / 1000 \mathrm{~kg} / \mathrm{m}^{3}=4497 \mathrm{lit} / \mathrm{hr}$

Then depend on the amount of utility entered to the boiler, the volume of boiler required for our capacity we select is 5000lit.

c. Design of the fan

The criteria of the fan have to be fulfilled is: $200 \mathrm{rpm}$ (tangential velocity of the fan), $\Theta=12^{\circ}$ ( 0.03 revolution) inlet angle of fluid to the fan Average temperature of Adama city at atmospheric pressure is $28^{0} \mathrm{c}$.

The amount of air required for combustion in this process determined at material balance is $120 \mathrm{~kg} / \mathrm{hr}$.

$$
\mathrm{M}=28.9 \mathrm{~kg} / \mathrm{kmol}, \mathrm{R}=8314.3 \mathrm{KJ} / \mathrm{kg}, \mathrm{T}=28+272=300 \mathrm{~K}
$$

$\rho_{\text {air }}=\mathrm{m} / \mathrm{v}=\mathrm{PM} / \mathrm{RT}$

where M-molecular weight of air, P-pressure of air (1 atm),

R-universal gas constant, T-temperature of air in Kelvin, $\rho_{\text {air }}$

$=1 \times 10^{5} \times 28.9 / 8314.3 \times 300=1.16 \mathrm{~kg} / \mathrm{m}^{3}$

Density of air $=$ mass air/volume of air

Volume of air $=$ mass of air/density of air $=120 / 1.16=$ $103.4 \mathrm{~m}^{3} / \mathrm{hr}=0.02872 \mathrm{~m}^{3} / \mathrm{hr}$.

The capacity $(\mathrm{Q})$ of fan is the calculated as:-

$\mathrm{Q}=\mathrm{V} \times \mathrm{D}_{\mathrm{f}} \times \mathrm{\theta}, \mathrm{V}=\pi \times \mathrm{D}_{\mathrm{f}} \times \mathrm{U}$

Where, V- velocity air, $\mathrm{D}_{\mathrm{f}}$ fan diameter, U- Tangential velocity of fan, $\Theta$ - angle of air at which it inlet to the fan. Substitute the velocity equation to the capacity equation and solve for diameter then the equation is become to:

$\mathrm{D}_{\mathrm{f}}=\sqrt{ }(\mathrm{Q} / \pi \times \mathrm{u} \times \Theta)=\sqrt{ }(0.02872 / 3.14 \times 3.3 \times 0.03)=$ $0.34 \mathrm{~m}=13.4$ inch. Then the fan diameter relative to our design exist is $15 \mathrm{inch}$. Therefore we select $15 \mathrm{inch}$ diameter fan for plant design in case of our project.

Bag filter

Calculating the volume of bag filter

Mass in let $537.47 \mathrm{~kg} / \mathrm{hr}$, Density of stuck gas is $1.45 \mathrm{~kg} / \mathrm{m}^{3}$ $v=\frac{\mathrm{m}}{\rho}=4447.4 \mathrm{~m}^{3}$

Average filtration $=50 \mathrm{~L} / \mathrm{m}^{2} / \mathrm{hr}$ to finish the filtration in $6 \mathrm{hr}$

The filteration area required $=\frac{4447.4 \mathrm{~L}}{50 \mathrm{~L} / \mathrm{m}^{2} \mathrm{hr} \times 6 \mathrm{hr}}=14.8 \mathrm{~m}^{2}$

\section{Scrubber}

The volume of scrubber $2500 \mathrm{~L}$, Average scrubbing rate 75 $\mathrm{L} / \mathrm{m}^{2} / \mathrm{hr}$

To finish the scrubbing in 6 hours the scrubbing area required can be calculated as

$$
\text { Scrubbing area }=\frac{25000 \mathrm{~L}}{\frac{75 \mathrm{~L}}{\mathrm{~m}^{2} \mathrm{hr}} \times 6 \mathrm{hr}}=55.56 \mathrm{~m}^{2}
$$

\subsubsection{Economical Analysis}

Plant Components and Cost Breakdown

Table 6. Summarized equipment capacity and price [10].

\begin{tabular}{llllccc}
\hline No & Equip name & Quantity & Material & Capacity & Unit price (\$) & Amount price (\$) \\
\hline 1 & Furnace & 1 & Carbon steel & $1600 \mathrm{~kg} / \mathrm{hr}$ & 263000 & 767500 \\
2 & Boiler & 1 & Carbon steel & $3000 \mathrm{~kg} / \mathrm{hr}$ & 43000 & 4300 \\
3 & wet scrubber & 1 & Carbon steel & $56 \mathrm{~m}^{2}$ & 16000 & 16000 \\
4 & Bag & 1 & Carbon steel & $15 \mathrm{~m}^{2}$ & 1400 & 5600 \\
5 & Filter & 4 & Carbon steel & $15 \mathrm{inch}$ & 1056400 \\
Total & & & & & & \\
\hline
\end{tabular}

Total purchasing equipment cost $=\$ 1056400$

Purchased equipment cost $=40 \%$ fixed capital investment

$$
\mathrm{FCI}=\frac{\$ 1056400=\$ 2641000}{0.4}
$$

$\mathrm{TCI}=\mathrm{FCI}+\mathrm{WC}$

$\mathrm{WC}=15 \% \mathrm{TCI}$
$\mathrm{TCI}=\mathrm{FCI}+15 \% \mathrm{TCI}$

$\mathrm{TCI}-0.15 \mathrm{TCI}=\mathrm{FCI}$

$0.85 \mathrm{TCI}=\mathrm{FCI}$

$$
\mathrm{TCI}=\frac{\$ 2641000=\$ 3107058.8}{0.85}
$$

$\mathrm{WC}=0.15 \times \$ 3107058.8=\$ 466058.8$ 
Table 7. Summarized value of direct and indirect costs.

a. Direct cost

\begin{tabular}{lll}
\hline Component & $\begin{array}{l}\text { Average\% } \\
\text { of FCI }\end{array}$ & Amount (\$) \\
\hline Purchased equipment cost & 40 & 1056400 \\
Purchased equipment installation cost & 10 & 264100 \\
Instrumentation and control cost & 5 & 132050 \\
Piping cost & 9 & 237690 \\
Electrical and size reduction equipment cost & 6 & 158460 \\
Building & 10 & 264100 \\
Service facilities & 14 & 369740 \\
Yard improvement & 3 & 79230 \\
Total & 82 & 2561770 \\
\hline
\end{tabular}

b. Indirect cost

\begin{tabular}{lll}
\hline Component & Average\% of FCI & Amount (\$) \\
\hline Engineering super vision & 8 & 211280 \\
Construction expense & 7 & 184870 \\
Contractor fee & 3 & 79230 \\
Total & & 475380 \\
\hline
\end{tabular}

TFCI is equals to Total direct and indirect cost $(\mathrm{D}+\mathrm{I})=$ $\$ 2561770+\$ 475380=\$ 3037150$

Total product cost estimation

Total product cost $=$ manufacturing cost + general expense

Raw material cost $=(10-50 \%$ of total product cost $)$

Since the raw material cost is included in working capital investment

Direct production cost (DPC) about $60 \%$ of TPEC (total

Purchased equipment installation cost)

$\mathrm{DPC}=0.6 \times \$ 264100=\$ 158460$

Raw material cost $=50 \%$ working capital

$$
=0.5 \times \$ 466058.8
$$

Working capital cost $=50 \%$ Total product cost

Total product cost $(\mathrm{TPC})=\$ 23302.94 / 0.5=\$ 46605.88$

i Operating Labor (OL): (10-20\% of total product cost) Consider the cost of operating labor $=15 \%$ of total product cost

$=0.15 \times \$ 46605.88=\$ 6990.88$

ii Direct Supervisory and Clerical Labor (DS \& CL): (10$25 \%$ of OL) Consider the cost for Direct supervisory and clerical labor $=12 \%$ of OL $=0.12 \times \$ 6990.88=\$ 838.9$

iii Utilities: $(10-40 \%)$ of total product cost) Consider the cost of Utilities $=30 \%$ of total product cost Utilities cost $=\$ 0.3 \times$ TPC $=0.3 \times \$ 46605.88=\$ 13981.7$

iv Maintenance and repairs (M \& R): (2-10\% of fixed capital investment) Consider the maintenance and repair cost $=3 \%$ of fixed capital investment

$\mathrm{v}$ Maintenance and repair cost $=0.03 \times \$ 2641000=$ $\$ 79230$

vi Operating Supplies: (10-20\% of M \& R or $0.5-1 \%$ of FCI)

Consider the cost of Operating supplies $=10 \%$ of $M \&$ $\mathrm{R}$

Operating supplies cost $=0.1 \times \$ 79230=\$ 7923$

viiPatent and Royalties: (5\% of total product cost)

$=\$ 0.05 \times 46605.88=\$ 2330.3$

Fixed charge $=15 \%$ Total product cost
$=0.15 \times \$ 46605.88=\$ 6990.88$

Plant overhead cost $=10 \%$ Total product cost

$=0.1 \times \$ 46605.88=\$ 4660.6$

Manufacturing cost $=$ Direct production cost + Fixed charge + Plant over head cost

$=\$ 158460+\$ 6990.88+\$ 4660.6=\$ 170111.48$

a. General expense

General expenses $=$ Administrative costs + distribution and selling costs + research and development costs.

i Administrative costs:(3\% of TPC)

Administrative costs $=0.03 \times \$ 46605.88=\$ 1398.2$

ii Distribution and Selling costs: $(2-20 \%$ of total product cost); this includes costs for sales offices, salesmen, and advertising. Consider the Distribution and selling costs is eqaul $10 \%$ of total product cost. Distribution and selling costs $=0.1 \times \$ 46605.88=\$ 4660.6$

iii Research and Development costs: (about 3\% of total product cost)

Consider the Research and development costs $=3 \%$ of total product cost

Research and development costs $=0.03 \times \$ 46605.88$ $=\$ 1398.2$

D. Financing (interest); (5\% of TCI $)=0.05 \times \$ 3107058.8$ $=\$ 155352.94$

Let now calculate the Gross profit and Net profit

Gross profit $=$ total income - total production cost depreciation cost

Depreciation cost $=6 \% \mathrm{FCI}$

$=0.06 \times \$ 2641000=\$ 158460$

For our production rate $=20313534.6 \mathrm{KWh} /$ year

In Ethiopian selling price standard $1 \mathrm{kw} / \mathrm{hr}=0.35$ ethio birr $=\$ 0.0175$

Income $=$ selling price $\mathrm{x}$ production per day $\mathrm{x}$ working day per year

$=\$ 0.0175 / \mathrm{kwh} \times 20313534 \mathrm{kwh} /$ year $=\$ 355486.9 /$ year

Gross profit $=$ total income - total production cost

$=\$ 355486.9-\$ 46605.88=\$ 308880.97$

Net profit $=$ Gross profit (1-income tax rate)

$=(1-0.02) \times \$ 308880.97$

$=\$ 302703.35 /$ year

E. Rate of Return on Initial Investment (ROI)

$$
\mathrm{ROI}=\frac{\text { net proffit }}{\text { total capital investment }}=\frac{\$ 302703.35}{3107058.8} \times 100=10 \%
$$

Commonly used profitability standards generally based on the highest rate of Earning. Taking 5\% of new capacity with established of energy generation from the power plant from this result the project is feasible.

F. Payback period

Salvage value of the factory is $\$ 150000$

$\mathrm{PBP}=\frac{\mathrm{FCI}-\text { salvage }}{\text { net profit }+ \text { depriciation }}=\frac{\$ 2641000-\$ 150000}{\$ 302703.35+\$ 158460}=5.6$ year

\subsubsection{Environmental Analysis and Plant SITE}

(I) Environmental analysis

Environmental benefit of energy generation from solid waste plant is: 
Use solid waste for the source of energy generation is avoid the environmental impact such as health problems, pollute the soil and water, gases emission to the atmosphere from the disposal site and others.

In the other case solid waste is one of the alternative energy sources. This shows that solid waste use for energy generation minimizing the environmental impact by reducing the usage of non renewable energy sources.

The flue gas constitutes of dust and hazardous substances in gaseous form that needs to be removed before the flue gas is released into the atmosphere in order to fulfill the environmental standards. The concentration of the pollutants of the flue gas depends on the waste composition and also on the incineration conditions. The air pollution Problems are solved primarily by building tall stacks. The wet scrubbers are often used in flue gas treatment to reduce substances as hydrogen chloride $(\mathrm{HCl})$, hydrogen fluoride (HF) and sulphur oxides (SOx) emission in atmosphere after this equipment the bag filer used to also removed the particulate matter. The waste water from wet flue gas cleaning must be treated at the site in accordance with the local waste water standards before being discharged to a sewer or directly into the final recipient. The presence of small concentrations of toxic materials in the salty waste water requires sophisticated chemical treatment technology to meet common standard.

(II) Plant site

Site selection criteria:

a. The availability of transportation considered

b. A good working environment is preferable for the workers

c. Distance from waste generation area must be also considered

d. Type of soil is also must be considered to avoid lechate

e. Population density or number of people live that area also considered

Therefore depending on the above criteria we choose Nazareth (Adama) town waste disposal area (on the road of Addis Ababa around the wind power) is better for erecting of energy recovery plant from solid waste than another place since that area is not good much for living of population because of geographical sitting.

\section{Result}

Based on the data gathered through questioner, observation, from primary and secondary sources, the Municipal solid waste management system setup, i.e., the solid waste collection and disposal operation in the city generated data given here under Table 8 below.

Table 8. The total energy gain from solid waste disposal operation and profit in Adama city generated data.

\begin{tabular}{lllll}
\hline Total waste & Capacity of Energy generation & Payback time & profit & Rate of Return on Initial Investment \\
\hline $71700 \mathrm{~m}^{3}$ annually & $3.1 \mathrm{MW}$ annually & 5.6 year & $\$ 302703.35 /$ year & $10 \%$ \\
\hline
\end{tabular}

\section{Discussion}

Disposal of Solid waste suffers both Health problem and environmental pollution. Still Ethiopia is pure in treatment of solid waste management system and this study gives a good outlook for countries like Ethiopia to play and implement in effective policy design and emphasis to development of energy generation plant from solid waste and enhancing modern access at all city's level.

Moreover, energy that recovers from solid waste had different uses such as industrial, domestics and commercial purpose. Incinerator of solid waste for energy recovery is important technology that reduces the environmental impact and increase economic profit. Thus, collected solid waste from Adama (Nazareth) city; (71700 $\mathrm{m}^{3}$ ) annually and can generate $20313534.6 \mathrm{kwh} /$ year energy or $3.1 \mathrm{MW}$ electricity and the profit is $\$ 302703.35 /$ year. The Payback period of the investment of the plant was determined within acceptable level of time (5.6year). So, economically, socially and politically site of view those study give impasses to the faceable Waste-toEnergy scheme and to implement into a larger scale because the revenue from the electricity sales will be able to offset the operating costs in a shorter time span and introduce energy generation plant from solid waste in Nazareth-Ethiopia. Those, Adama/Nazareth city Administration could be more profitable, implement incineration with energy recovery plant for better production of electricity. Further study should be carried out under ideal circumstances of sorting, processing, and recycling these materials should go to different destinations.

\section{Conclusion}

Awareness amongst the city administrative about the benefits of integration of various technologies for Municipal solid waste processing is lacking. This is necessary as different technological options are required for Treating the different components of waste, such as Composting/ Biomethanation process for Organic component, incineration/ gasification/ Refused derived fuel process for Combustibles portion of waste, inert management facility for Construction and Demolition waste, etc.

Government should have a role to play at all levels federal and state in effective policy design and emphasis could be given to development of energy generation plant from solid waste and enhancing modern access at all city level of Ethiopia.

Labor that work at power plant should easily accessible for educational program. The waste that generates from the plant is must not disposed to the environment before treatment. As a general recommendation the implementation of waste to energy should be transform 
into large-scale schemes.

\section{References}

[1] Ayodeji Ifegbesan, Exploring secondary school students' understanding and practices of waste management in Ogun State, Nigeria, International jornual of environmental \&science education, Vol. 5, No. 2, April 2010, 201-215.

[2] L. A. Guerrero, G. Maas, and W. Hogland, Solid waste management challenges for cities in developing countries. Waste Management, 2013. 33: p. 220-232.

[3] R. Marshall, and K. Farahbakhsh, Systems approaches to integrated solid waste management in developing countries. Waste Management, 2013. 33: p. 988-1003.

[4] Mesfin Assefa1, Muktar Mohammed2, Solid Waste Generation Rate and Characterization Study for Laga Tafo Laga Dadi Town, Oromia, Ethiopia, International Journal of Environmental Protection and Policy 2017; 5 (6): 84-93.

[5] Adama town Administration Municipality, 2005.

[6] Harker JH, Buckhurst JR. Fuel and energy, Composition of municipal waste arising in the European country, London: Academic Press, 1981.

[7] John W. Bartok, Heating value of each component of solid waste (Approximate Heating Value of Common Fuels), December 2004)

[8] Journal of the Air and Waste Management Association, 1996.
[9] http://www.matche.com, 2013.

[10] Kreith F. (1994), Hand book of Solid Waste Management, Mc Graw-Hill Inc. U.S.A.

[11] Berenyi, E. (1999), Methane Recovery from Landfill Yearbook, 5th Edition, Governmental Advisory Associates, Westport, CT.

[12] Brady, M. H. (2000), "Materials and Energy Recovery from the Dry Stream of New York City's Residential Waste", M. S. Thesis, Earth and Environmental Engineering, Columbia University, New York, NY 10027.

[13] Municipal solid wastes (management and handling) rules, 2000 annual report 2004-2005.

[14] Tchobanoglous G., Theisen H., and Eliasssen R., 1977. Principles and Management Issues Mc Grow-Hill Kogakush, Tokyo. Solid Waste Engineering.

[15] Brady, M. H. (2000) "Materials and Energy Recovery from the Dry Stream of New York City's Residential Waste”, M. S. Thesis, Earth Resources Engineering, Columbia University.

[16] Walsh 2000, Walsh, D. C., S. N. Chillrud, H. J. Simpson, and R. F. Bopp, 2000, "Refuse Incinerator Particulate Emissions and Combustion Residues for New York City during the 20th Century", Environmental Science and Technology, in press.

[17] Lema Asfaw. Truck in a duty of primary and secondary waste collection. Journal of Environmental Science (2004).

[18] Julius N. Fobil. Evaluation of municipal solid wastes (MSW) for utilization in energy production in developing countries (2005). 